Adem YAĞCl

Ahmet Gökhan GÖKKAYNAK²

1 Gaziosmanpaşa Üniversitesi, Ziraat Fakültesi, Bahçe Bitkileri Bölümü, 60250, Tokat /Türkiye

2 Gökkaynak Fidancllık, 45400, Manisa / Türkiye

Sorumlu Yazar: adem.yagcı@gop.edu.tr

Anahtar Sözcükler:

$110 \mathrm{R}$, ramsey, aşılama, amerikan asma anacl

Key Words:

$110 \mathrm{R}$, ramsey, grafted, rootstock

\section{Sultani Çekirdeksiz Üzüm Çeşidinin Fidan Randımanı ve Kalitesi Üzerine Anaç ve Gölgeleme Oranının Etkisi}

\author{
The Effect of Rootstock and Shading Ratio on Seedling \\ Performance And Quality of Sultani Çekirdeksiz Grape Cultivar
}

Alınış (Received):27.08.2015 Kabul tarihi (Accepted): 02.02.2016

\begin{abstract}
ÖZET
u çalışma Manisa (Turgutlu) ekolojik koşullarında 2012 yılında yürütülmüştür. B Çalışmada 5 Amerikan asma anacı (140 Ruggeri, 110 R, Ramsey, 1613 C ve 5 BB), Sultani Çekirdeksiz üzüm çeşidi ve \% 35, \% 55 ve \% 75 gölgeleme oranları kullanılmıştır. Bu araştırma, 5 Amerikan asma anacı (140 Ruggeri, 110 R, Ramsey, $1613 \mathrm{C}$ ve 5 BB) üzerine aşılı 'Sultani Çekirdeksiz' üzüm çeşidinin fidan randımanı ve kalitesi üzerine \% 35, \% 55 ve \% 75 gölgeleme oranlarının etkisini belirlemek amacı ile 2012 yılında Manisa (Turgutlu) ekolojik koşullarında yürütülmüştür. Kontrol uygulamasında herhangi bir gölgeleme yapılmamıştır. Çalışmada aşılama işlemleri masa başında omega aşı tekniği kullanılarak makine ile yapılmıştır. Fidan sökümü Aralık 2012 tarihinde gerçekleştirilmiştir. Çalışma sonucunda kök sayısı, kök gelişim düzeyi, sürgün gelişim düzeyi ve fidan randımanı değerleri, gölgeleme ve anaç uygulamalarından önemli derecede etkilenmiştir. Toplam fidan randımanı bakımından en iyi sonucu \% 55 gölge (\% 58.4) uygulaması verirken bunu kontrol ve \% 35 gölge (\% 49.9) ile \% 75 gölge (\% 41.5) takip etmiştir. Yoğun gölge altında yetişen fidanların hem toprak altı hem de toprak üstü organlarında diğer uygulamalara göre daha zayıf bir gelişim gözlemlenmiştir.
\end{abstract}

\section{GíRiş}

Bağ alanlarında filoksera, nematod ve diğer bazı hastalık ve zararlıların etkisiyle sürekli verimden düşen veya elden çıkan bağların kontrollü bir şekilde yenilenmesi gerekmekte ve bunun için her yıl milyonlarca fidana ihtiyaç duyulmaktadır (Çelik ve ark., 1996; Çelik ve ark., 2005; Çelik, 2011; Yağcı ve Aydin, 2012). Türkiye de üretilen toplam asma fidanı miktarı yıllara göre büyük değişiklikler göstermektedir. Bu miktar 2013 yılı için 7146290 adettir (Anonim, 2014). $\mathrm{Bu}$ miktar Türkiye'nin asma fidanı ihtiyacını karşılayamamaktadır. Manisa ili ülkemizde asma fidanı üreten kuruluşların merkezi konumundadır. Çelik (2012) ülkemizde üretilen toplam asma fidanın \% $68^{\prime}$ inin, aşılı asma fidanın ise \% 79'unun Manisa ilinden karşılandığını bildirmektedir. 
Bağcılıkta tüplü ve açık köklü olarak fidan üretimi yapılmaktadır. Açık köklü asma fidanı üretimi ile kıyaslandığında, tüplü asma fidanı üretimi ile daha yüksek randıman ve kısa zamanda kazanç sağlanmaktadır. Ancak ilk tesis masrafının yüksek olması, daha çok el emeğine ve kontrollü kapalı ortamlara ihtiyaç duyması açık köklü fidan üretimine göre öne çıkan başlıca dezavantajlarıdır (Akman ve ılgın, 1987, 1991; Çelik ve ark., 1989; Ece, 2003; Çelik, 2011).

Kamu veya özel sektör tarafından yapılan asma fidanı üretiminde fidan randımanı \% 25-40 arasında değişmektedir (Çelik ve Ağaoğlu, 1981; Akman ve llgın, 1991; Çelik, 2011). Asma fidanı üretiminde fidan randıman ve kalitesi üzerine; aşı materyallerinin alındığı omcaların beslenme, sağlık ve gelişme durumları (Çelik ve ark., 1998), çeliklerin saklanma koşulları (Çelik ve Ağaoğlu, 1979), çeliklerin bünyelerinde bulunan su miktarı (Kısmalı, 1978), kalemlerin katlama sıcaklığı ve süresi (Sucu ve Yağcı, 2013), aşılama yöntemi ile aşı sırasında gösterilen titizlik (Çelik ve Odabaş, 1995; Erdem ve Ergenoğlu, 1995; Ecevit ve Baydar, 2000), aşılama zamanı (Winkler ve ark., 1997; Çelik, 1995; Çelik ve ark., 1998), aşılama ve kaynaştırma sonrasında ortam koşulları (Eriş ve ark., 1989), farklı parafin uygulamaları (Cangi ve ark., 1999), malç uygulamaları ve dikim sonrası yapılan bakım koşulları (Weshuizen, 1980; Kelen, 1994), çeşit/anaç kombinasyonları (Kısmalı, 1978; Samanci ve Uslu, 1992; Cangi ve ark., 1999; Ecevit ve Baydar, 2000; Sivritepe ve Türkben, 2001) ve örtü materyalinin de içinde bulunduğu (Çelik ve Odabaş, 1996) pek çok faktör etki etmektedir.

Açık köklü fidan üretiminde gölge oranı fidan randımanı ve kalitesini önemli derecede iyileştirmektedir (Yağcı ve ark., 2012; Yağcı ve Aydin, 2012). Yüksek sıcaklığın olduğu dönemlerde güneşin yakıcı etkisinin azaltılmasına ilave olarak düşük ışık ve optimal sıcaklık şartlarının sağlanması, yüksek ışık ve düşük sıcaklık şartlarına göre fidan randımanı ve kalitesini olumlu etkilemektedir (Köse, 2006)

Manisa ilinin coğrafi konumu nedeniyle gelişme periyodu erken başlamakta ve havalar erken ısınmaktadır. Fakat açık köklü fidan üretiminde kullanılacak aşılı materyallerin dikimleri geç tarihlere kalmaktadır. Bu durumun özellikle fidan randımanında istenmeyen sonuçlara neden olmaktadır. Bu amaç ile gölgeleme uygulaması ile sıcaklığın belli sınırlar içerisinde tutulacağı ve aşırı sıcakların olumsuz etkilerinden korunulabileceği düşünülmektedir.

Bu çalışma ile farklı anaçlar üzerine aşılanmış Sultani Çekirdeksiz üzüm çeşidinin fidan randımanı ve kalitesi üzerine farklı gölgeleme uygulamalarının (\% 35, \% 55 ve $\% 75$ ) etkisini belirlemek amaçlanmıştır.

\section{MATERYAL ve YÖNTEM}

\section{Materyal}

Bu çalışmada anaç materyali olarak $110 \mathrm{R}, 1613,5 \mathrm{BB}$ 140 Ruggeri ve Ramsey; kalem olarak ise Sultani Çekirdeksiz çeşidi kullanılmıştır. Çalışma Manisa ili Turgutlu ilçesinde bulunan bir üretici arazisinde yürütülmüştür. Arazi hafif alkali karakterde $(\mathrm{pH}: 7,55)$ hafif kireçli (CaCO3: \% 4,13) organik maddesi az (\%1.14), tınlı bünyede ve tuzsuz (saturasyonda \%0,014) toprak yapısına sahiptir.

Örtü materyali olarak \%100 polipropilen'den üretilmiş ve dayanıklıı̆ı arttırmak için UV katkısı bulunan \% 35, \% 55 ve $\% 75^{\prime}$ lik gölgeye sahip netler kullanılmıştır. Kontrol amaçlı parselde herhangi bir örtü kullanılmamıştır. Her gölge oranı altına; sıcaklık, nem ve ışıklanma şiddetini ölçmek amacıyla 30 dakikada bir veri alan datalogger (ONSET-HOBO marka, veri U12 model) yerleştirilmiştir.

\section{Yöntem}

Anaçlara ve çeşide ait çelikler Ağaoğlu ve ark (1979)'a göre muhafaza edilmiştir. Aşılama öncesi çelikler Agrobacterium vitis'e karşı 30 dakika $50{ }^{\circ} \mathrm{C}^{\prime}$ de sıcak suda bekletilmişsir. Aşılama işlemi (25 Mart 2012) yarı otomatik, pedallı ve omega şeklinde kesit açan makine ile yapılmıştır.

Katlama ortamı olarak çam talaşı kullanılmıştır. Kaynaştırma odası (oda hacmi: $4 \times 5 \times 3 \mathrm{~m}$, katlama kasaları: $37 \times 57 \times 40 \mathrm{~cm}$ ebadında-500 aşılı materyal kapasiteli) koşulları: 3 gün $28-29^{\circ} \mathrm{C}$, 15 gün $25-26^{\circ} \mathrm{C}$ ve 3 gün $22-24{ }^{\circ} \mathrm{C}$; nem oranı $\% 85-95$; 6-12 saatte bir havalandırma (Çelik, 1982; Akman ve Ilgın, 1991) olacak şekilde düzenlenmiştir. Fidanlar, kaynaştırma odasından çıkarılan kasalarda 2 gün gölge bir yerde bekletilmiş ve daha sonra üzerlerindeki iri talaşlar alınmıştır. Talaşlar alındıktan sonra 4 gün daha gölge ve sıcaklığın $20-22^{\circ} \mathrm{C}$ olan odada bekletilmiştir (kallus'ta renk dönüşümünün olduğu ana kadar). íkinci parafinleme (Actygref, Fransa) sonrası çeliklerin dipleri 2000 ppm'lik IBA (100354Indole-3-butyric acid, Merck) ile hızlı daldırma ile muamele (Sağlam ve ark., 2005) edilerek dikilmiştir.

15 Nisan tarihinde çalışmanın kurulacağı alan öncelikle üçlü pullukla sürülmüş ve rotatil çekilerek büyük kesekler kırılmış, tırmık ile tesviye yapılmıştır. Masuraları oluşturmak için traktörün arkasına takılan masura makinesinden faydalanılmıştır. Her masuraya 15 cm'de bir damlatıcısı olan 1 damlama borusu çekilmiş ve $10 \times 20 \mathrm{~cm}$ dikim deliklerine sahip siyah plastik malç ile kaplanmıştır. Masuralar oluşturulurken örtü malzemesine iskelet montajı yapılmış ve $\% 0,35,55$ ve 75 gölgeleme oranına sahip örtüler (netler) çekilmiştir (Şekil 1 ve 2). 


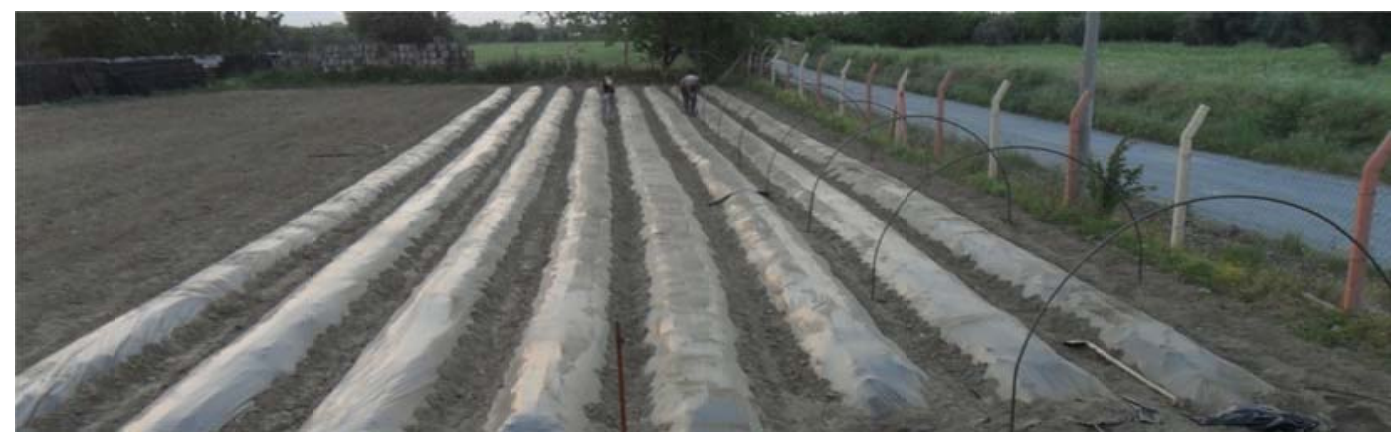

Şekil 1. Plastik malç serilmesi

Figure 1. Mulching with black plastic

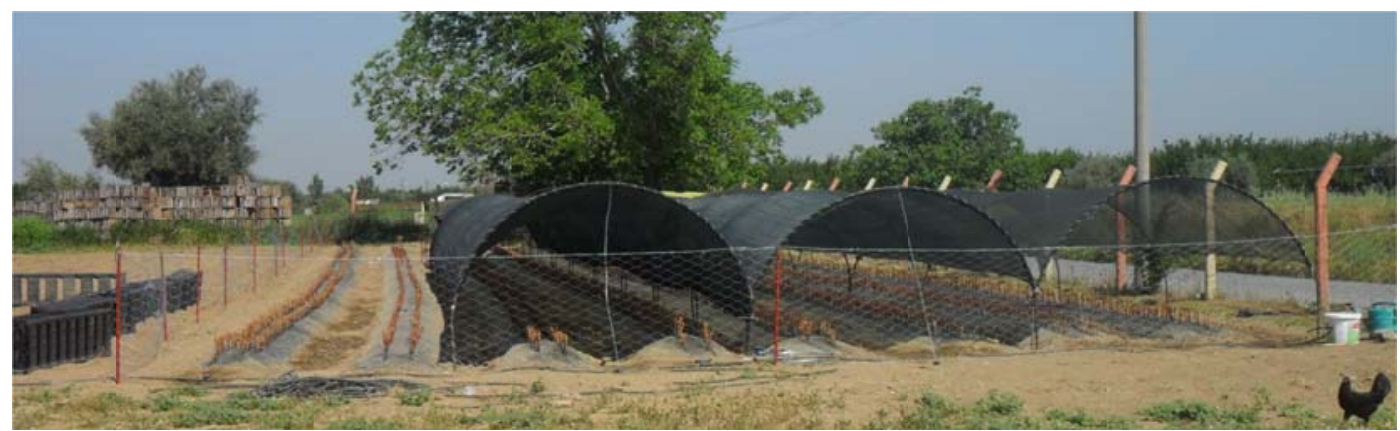

Şekil 2. Gölgeliklerin çekilmesi

Figure 2. Shading

Gölge materyallerinin altına aşıı çelikler 21 Nisan tarihinde masuralara dikilmiş, gölge materyalleri 1 Ağustos 2012 tarihinde fidanların üzerinden kaldırılmış ve fidan sökümü 26 aralık 2012 tarihinde gerçekleşmiştir
(Çelikler 103 gün gölge altında 146 gün açıkta kalmıştır). Sulama, gübreleme (humik asit), hastalıklarla (Cupravit ve Shavit) mücadele düzenli olarak yapılırken, yabancı ot mücadelesi (çapa ve el ile) gerektikçe yapılmıştır (Şekil 3).

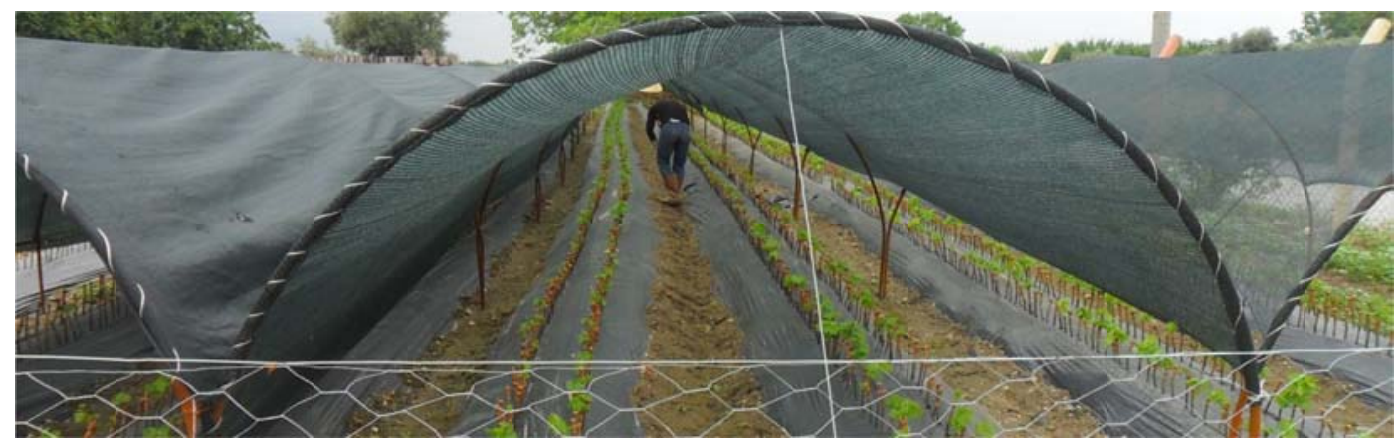

Sekil 3. Yabancı ot mücadelesi

Figure 3. Weed control in area

Fidanlarda;

- Kök sayısı (adet): kök çapı 2 mm den kalın olan kökle sayılarak edet olarak verilmişti.

- Kök gelişim düzeyi: 0-4 skalasına göre 5 gruba ayrılmıştır ( 0- gelişme yok, 1-zayıf, 2-orta, 3-kuvvetli, 4-çok kuvvetli).

- Sürgün gelişim düzeyi: 0-4 skalasına göre5 gruba ayrılmıştır ( 0- gelişme yok, 1-zayıf, 2-orta, 3kuvvetli, 4-çok kuvvetli).
- Fidan randımanı: Aşağıdaki eşitlik yardımı ile hesaplanmıştır.

$$
F R=\left[\frac{S F S}{D F S}\right] \times 100
$$

Eşitlikte; FR= Fidan Randımanı (\%); SFS= Sökülen Fidan Sayısı (adet); DFS= Dikilen Fidan Sayısı (adet) dır.

Elde edilen fidanlar TSE (1995)'e göre I. ve II. boy olarak gruplandırılmıştır. 


\section{Deneme Planı ve İstatistiksel Analiz}

Çalışmada 5 anaç $\times 4$ uygulama (biri kontrol) $\times 3$ tekerrür x 200 aşılı çelik olarak, bölünmüş parseller deneme desenine göre tertip edilmiş ve elde edilen veriler varyans analizine tabi tutulduktan sonra ortalamaların karşılaştııılmasında LSD $(<0,05)$ testi uygulanmıştır.

\section{ARAŞTIRMA BULGULARI ve TARTIŞMA}

Farklı gölde düzeylerinin sıcaklık, nispi nem ve ışıklanma üzerine etkileri

Yetiştiricilik döneminde örtü altı ve kontrol uygulamalarından 30 dakika ara ile sıcaklık, nem ve ışıklanma miktarları verileri alınmıştır. Farklılıkların daha iyi görülebilmesi için 14-31 temmuz tarih aralığındaki değerler gün olarak ve 15 Temmuz tarihindeki değerler ise 24 saat üzerinden verilmiştir. 14-31 Temmuz arasında gölgeleme uygulamaların; ortalama sıcaklık değerleri kontrol uygulamasında $30.0^{\circ} \mathrm{C}, \% 35$ ve $\% 55$ gölgelikte $29.6{ }^{\circ} \mathrm{C}, \% 75^{\prime}$ lik gölgelemede ise $29.8{ }^{\circ} \mathrm{C}$ olarak; ortalama nispi nem miktarı kontrol uygulamasında $\% 54.4$, \% 35 gölgelikte $\% 56.1 \% 55$ gölgelikte $\% 56.9$ ve $\% 75^{\prime}$ lik gölgelikte $\% 56.7$; ortalama ışıklanma miktarı $\left(\mathrm{W} / \mathrm{m}^{2}\right)$ kontrol uygulamasında 576.0, $\% 35$ gölgelikte 170.1 , \%55 gölgelikte 35.8 ve $\% 75^{\prime}$ lik gölgelikte $26.2\left(\mathrm{~W} / \mathrm{m}^{2}\right)$ meydana gelmiştir (Çizelge 1).

Çizelge 1. Farklı ortamlardaki ortalama sıcaklık $\left({ }^{\circ} \mathrm{C}\right)$, nisbi nem (\%) ve ışıklanma $\left(\mathrm{W} / \mathrm{m}^{2}\right)$ (14-31 Temmuz) Table 1. The average temperature $\left({ }^{\circ} \mathrm{C}\right)$, relative humidity (\%) and light quality ( $\left.\mathrm{W} / \mathrm{m} 2\right)$ in different shading ratio (14-31 Temmuz)

\begin{tabular}{|c|c|c|c|c|c|c|c|c|c|c|c|c|}
\hline \multirow{3}{*}{ Tarih } & \multicolumn{12}{|c|}{ Örtü materyalleri } \\
\hline & \multicolumn{3}{|c|}{ Kontrol } & \multicolumn{3}{|c|}{ \%35 gölge } & \multicolumn{3}{|c|}{ \%55 gölge } & \multicolumn{3}{|c|}{ \%75 gölge } \\
\hline & Sic. & Nem & Işık & Sic. & Nem & Işık & Sic. & Nem & Işık & Sic. & Nem & Işık \\
\hline 14.07 .2012 & 30.3 & 50.6 & 601.9 & 29.8 & 52.8 & 34.6 & 29.6 & 55.8 & 219.7 & 29.8 & 54.3 & 28.7 \\
\hline 15.07.2012 & 30.6 & 48.4 & 620.4 & 30.0 & 50.7 & 35.9 & 29.7 & 53.5 & 234.9 & 30.0 & 53.4 & 31.4 \\
\hline 16.07.2012 & 31.3 & 45.2 & 610.4 & 30.3 & 48.9 & 36.4 & 30.2 & 51.3 & 225.6 & 30.3 & 51.7 & 30.3 \\
\hline 17.07.2012 & 30.1 & 51.2 & 589.2 & 29.9 & 52.4 & 37.7 & 29.7 & 53.5 & 209.8 & 29.9 & 52.6 & 31.3 \\
\hline 18.07.2012 & 28.8 & 54.8 & 592.8 & 28.8 & 55.1 & 38.8 & 28.7 & 56.2 & 214.6 & 28.9 & 55.3 & 32.9 \\
\hline 19.07.2012 & 28.9 & 46.3 & 596.2 & 28.9 & 47.5 & 38.3 & 28.9 & 47.8 & 216.6 & 28.9 & 47.5 & 32.0 \\
\hline 20.07.2012 & 28.6 & 56.9 & 577.4 & 28.4 & 58.2 & 39.1 & 28.5 & 59.0 & 210.4 & 28.7 & 58.2 & 29.0 \\
\hline 21.07.2012 & 30.2 & 56.6 & 574.7 & 30.0 & 58.1 & 41.5 & 30.0 & 58.4 & 207.8 & 30.2 & 58.7 & 27.0 \\
\hline 22.07.2012 & 29.2 & 58.8 & 579.5 & 29.0 & 60.3 & 42.6 & 29.0 & 60.7 & 206.8 & 29.2 & 60.9 & 27.9 \\
\hline 23.07.2012 & 29.7 & 55.6 & 563.1 & 29.5 & 57.0 & 40.2 & 29.5 & 57.3 & 199.9 & 29.6 & 57.4 & 26.2 \\
\hline 24.07 .2012 & 30.4 & 60.5 & 568.8 & 30.1 & 62.1 & 41.4 & 30.3 & 62.0 & 205.1 & 30.4 & 62.1 & 26.4 \\
\hline 25.07.2012 & 30.3 & 64.1 & 568.5 & 30.0 & 65.9 & 39.0 & 30.0 & 66.2 & 147.2 & 30.3 & 65.7 & 25.0 \\
\hline 26.07 .2012 & 30.8 & 65.4 & 551.4 & 30.4 & 67.2 & 32.6 & 30.7 & 66.7 & 99.4 & 30.8 & 66.9 & 21.2 \\
\hline 27.07.2012 & 31.1 & 62.1 & 546.0 & 30.7 & 64.4 & 30.9 & 30.9 & 64.2 & 97.9 & 31.1 & 64.4 & 20.7 \\
\hline 28.07.2012 & 29.7 & 56.5 & 517.3 & 29.4 & 58.5 & 28.6 & 29.3 & 59.2 & 91.4 & 29.5 & 58.9 & 18.2 \\
\hline 29.07.2012 & 30.4 & 46.0 & 570.3 & 30.0 & 47.9 & 30.2 & 30.1 & 48.2 & 92.3 & 30.1 & 48.3 & 21.5 \\
\hline 30.07 .2012 & 29.7 & 49.3 & 592.7 & 29.1 & 51.3 & 30.9 & 29.1 & 52.1 & 80.6 & 29.0 & 52.6 & 22.0 \\
\hline 31.07 .2012 & 29.6 & 50.2 & 547.2 & 29.3 & 51.8 & 25.5 & 29.3 & 52.1 & 101.1 & 29.4 & 52.2 & 19.5 \\
\hline Ortalama & 30.0 & 54.4 & 576.0 & 29.6 & 56.1 & 35.8 & 29.6 & 56.9 & 170.1 & 29.8 & 56.7 & 26.2 \\
\hline
\end{tabular}

Karanlık periyotta sıcaklık değerleri kontrolde daha yüksek olmuştur. Sıcaklığın en yüksek olduğu saat 18:00'de kontrol uygulamasında $40{ }^{\circ} \mathrm{C}, \% 35$ gölgelik $37.9^{\circ} \mathrm{C}$, $\% 5$ gölgelikte $37.7^{\circ} \mathrm{C}$ ve $\% 75^{\prime}$ lik gölgelemede $38.2{ }^{\circ} \mathrm{C}$ ölçülmüştür (Şekil 4). Nisbi nemin gün içerisindeki değişimleri ISı ve ışığın varlığına göre değişebilmektedir. Geceden gün doğumuna kadar nem içeriği yüksek iken aydınlık periyotta sıcaklık ve ışığında etkisi ile daha düşük değerlere inmiştir. Örneğin saat 06:00'da kontroldeki nem miktarı \%78.6 iken \%35 gölgelikdeki nem miktarı \%80.5; saat 18:00'de ise değerler sırasıyla \%38.8 ve \%38.2 olmuştur (Şekil 5). Gölgelikler arasındaki ışık şiddeti farklı gün başlarken en yüksek değerde iken gün ortalarında fark bir miktar daha azalmaktadır. Örneğin en yüksek ışıklanma değerine sahip kontrolle diğerleri kıyaslandığında; saat 09:00'da kontrol \%100 kabul edilse \%35 gölgelik \%29,4; $\% 55$ gölgelik \%7,0; \%75 gölgelik \%2,4 olmaktadır. Bu oran saat $12: 00^{\prime}$ de ise sırasıyla $\% 100 ; \% 43,7 ; \% 5,8$ ve \%3,4 olmaktadır (Şekil 6). 


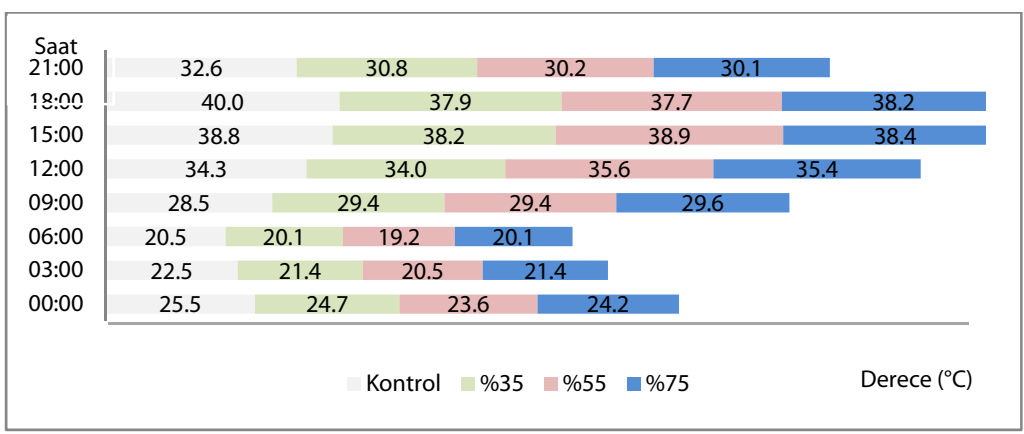

Şekil 4. 15 Temmuz tarihinde açıkta ve farklı gölge oranları altındaki sıcaklıklar $\left({ }^{\circ} \mathrm{C}\right)$

Figure 4. The temperatures in open field and different shade ratio in July $15\left(^{\circ} \mathrm{C}\right)$

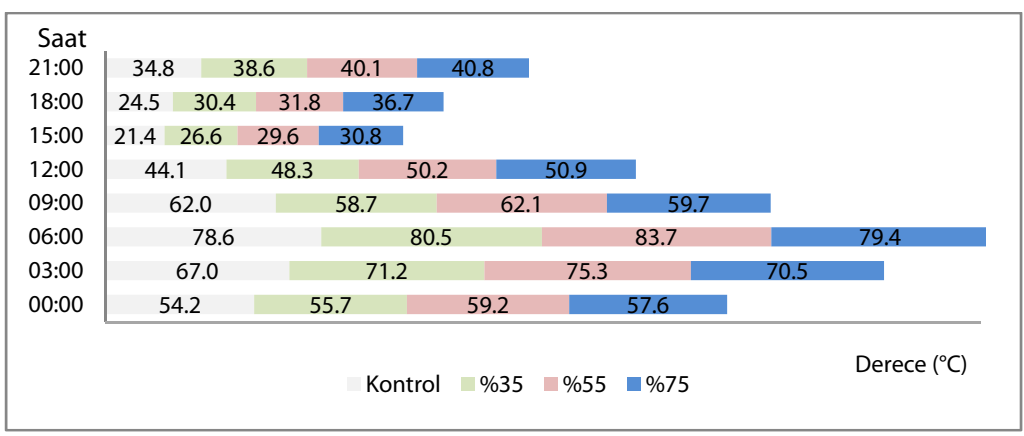

Şekil 5. 15 Temmuz tarihinde açıkta ve farklı gölge oranları altındaki nisbi nem (\%)

Figure 5. The Reletively humidity (\%) in open field and different shade ratio in July $15\left({ }^{\circ} \mathrm{C}\right)$

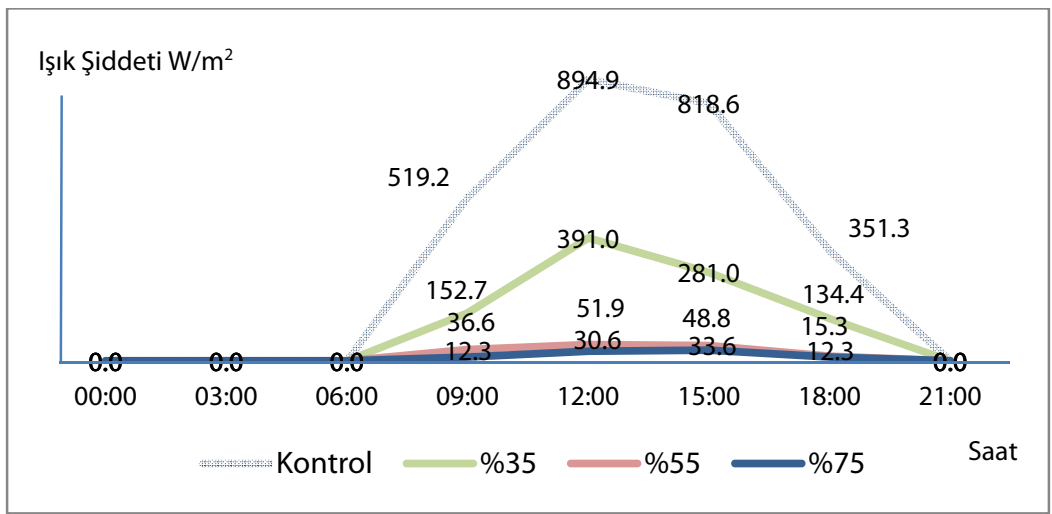

Şekil 6. 15 Temmuz tarihinde açıkta ve farklı gölge oranları altındaki Işık şiddeti değişimi $\left(\mathrm{W} / \mathrm{m}^{2}\right)$ Figure 6. The light intensity $\left(\mathrm{W} / \mathrm{m}^{2}\right)$ in open field and different shade ratio in July $\left.15{ }^{\circ} \mathrm{C}\right)$

Gölge oranı arttıkça sıcaklık değerlerinde özellikle gün içerisinde düşmektedir. Fakat karanlık dönemlerde yoğun gölgelikler ısıyı daha fazla tutmakta ve tam gün değerini yükseltmektedir. Nisbi nem gölge oranı arttıkça artmakta, ışıklanma ise düşmektedir. Elde edilen değerler Kesgin (2011), Yağcı ve Aydin (2012) ile Yağcı ve ark. (2012) ile benzerlik göstermektedir. Çalışmada \%75 gölge altındaki fidanların ışıktan yeteri kadar faydalanmadığı ve bu nedenle sürgün ve yaprak gelişiminin zayıf kalmasına neden olduğu düşünülmektedir. Yağcı ve Aydin (2012)'da fidanlardaki zayıf gelişmeyi benzer şekilde açıklamaktadır. Cartechini ve Palliotti (1995), asmaların beslenebilmesi için gerekli PAR değerinin yaklaşık 700 ile $900 \mu \mathrm{mol} \mathrm{m}^{-2} \mathrm{~S}^{-1}$ olması gerektiği ve $\% 30$ ve $\% 60$ gölgelikler altındaki asmaların gölge altına alınmayanlara göre PAR miktarının düşük olduğunu bildirmişlerdir. 


\section{Uygulamaların fidan randıman ve kalitesi üzerine etkileri}

Gölgeleme uygulamalarının 110 R, 140 Ruggeri, 1613

C, 5 BB ve Ramsey anaçları üzerine aşılanan Sultani
Çekirdeksiz üzüm çeşidinde, fidan randıman ve kalitesi bakımından kök sayısı, kök gelişim düzeyi, sürgün gelişim düzeyi ve toplam fidan randımanı bakımından elde edilen sonuçlar Çizelge 2 ve Çizelge 3'de verilmiştir.

Çizelge 2. Farklı anaç ve gölge oranlarının fidan kalite ve randımanı üzerine etkisi

Table 2. The effect of different rootstocks and shadow on sampling qality and the yield rate

\begin{tabular}{|c|c|c|c|c|c|c|}
\hline & \multirow{2}{*}{$\begin{array}{c}\text { Kök Sayısı } \\
\text { (adet) }\end{array}$} & \multirow{2}{*}{$\begin{array}{c}\text { Kök Gelişimi } \\
(0-5)\end{array}$} & \multirow{2}{*}{$\begin{array}{c}\text { Sürgün Gelişimi } \\
(0-4)\end{array}$} & \multicolumn{3}{|c|}{ Fidan Randımanı } \\
\hline & & & & I. Boy & II. Boy & Toplam \\
\hline $110 R$ & $8.0^{b}$ & $1.8^{b}$ & $2.6^{b}$ & $48.0^{b}$ & $3.5^{b}$ & $51.5^{b}$ \\
\hline 140 Ruggeri & $9.1^{b}$ & $1.5^{c}$ & $2.3^{b c}$ & $35.3^{d}$ & $5.1^{a b}$ & $40.4^{c}$ \\
\hline $1613 C$ & $14.0^{\mathrm{a}}$ & $3.1^{\mathrm{a}}$ & $3.9^{\mathrm{a}}$ & $45.9^{c}$ & $4.4^{\mathrm{b}}$ & $50.3^{b}$ \\
\hline $5 \mathrm{BB}$ & $14.8^{\mathrm{a}}$ & $2.9^{\mathrm{a}}$ & $4.0^{\mathrm{a}}$ & $50.9^{a}$ & $6.4^{\mathrm{a}}$ & $57.3^{a}$ \\
\hline Ramsey & $8.8^{b}$ & $1.6^{c}$ & $2.2^{c}$ & $46.4^{b c}$ & $3.8^{b}$ & $50.2^{b}$ \\
\hline LSD 0,05 & 2.1 & 0.2 & 0.3 & 2 & 1.8 & 3.1 \\
\hline Kontrol & $12.9^{a}$ & $2.1^{\mathrm{b}}$ & $3.3^{a}$ & $46.5^{b}$ & $3.3^{c}$ & $49.9^{b}$ \\
\hline \%35 gölge & $11.5^{b}$ & $2.4^{\mathrm{a}}$ & $2.9^{b c}$ & $45.9^{b}$ & $4.0^{b c}$ & $49.9^{b}$ \\
\hline$\% 55$ gölge & $12.2^{\mathrm{ab}}$ & $2.4^{\mathrm{a}}$ & $3.1^{\mathrm{ab}}$ & $53.7^{\mathrm{a}}$ & $4.8^{b}$ & $58.4^{\mathrm{a}}$ \\
\hline$\% 75$ gölge & $7.1^{c}$ & $1.8^{c}$ & $2.7^{c}$ & $35.0^{c}$ & $6.5^{\mathrm{a}}$ & $41.5^{\mathrm{c}}$ \\
\hline LSD $_{0,05}$ & 1.3 & 0.2 & 0.3 & 2.4 & 1.2 & 2.9 \\
\hline
\end{tabular}

Aynı sütundaki farklı harfler önemlidir $(0,05)$

Çizelge 3. Fidan kalite ve randıman üzerine Anaç x Gölge İnteraksiyonun etkisi

Table 3. The effect of rootstocks $x$ shadow interaction on sampling quality and the yield rate

\begin{tabular}{|c|c|c|c|c|c|c|c|}
\hline \multirow{2}{*}{$\begin{array}{c}\text { Gölge } \\
\text { Oranları }\end{array}$} & \multirow{2}{*}{ Anaçlar } & \multirow{2}{*}{ Kök Sayısı } & \multirow{2}{*}{$\begin{array}{c}\text { Kök } \\
\text { Gelişimi }\end{array}$} & \multirow{2}{*}{$\begin{array}{l}\text { Sürgün } \\
\text { Gelişimi }\end{array}$} & \multicolumn{3}{|c|}{ Fidan Randımanı (\%) } \\
\hline & & & & & I. Boy & II. Boy & Toplam \\
\hline Kontrol & \multirow{4}{*}{$110 \mathrm{R}$} & $10.1^{\text {de }}$ & $1.9^{\mathrm{fg}}$ & $2.7^{\text {cdef }}$ & 43.7 ghi & $3.7^{\text {def }}$ & $47.4^{\mathrm{fgh}}$ \\
\hline$\% 35$ & & $6.6^{\mathrm{fg}}$ & $2.7^{d}$ & $2.2^{\mathrm{efg}}$ & $51.8^{\text {cde }}$ & $2.4^{\mathrm{f}}$ & $54.2^{\text {cde }}$ \\
\hline$\% 55$ & & $8.5^{\text {defg }}$ & $1.4^{\mathrm{h}}$ & $3.0^{\mathrm{cd}}$ & $54.8^{b c}$ & $4.3^{\text {cdef }}$ & $59.2^{b c}$ \\
\hline$\% 75$ & & $6.6^{\mathrm{fg}}$ & $1.4^{\mathrm{h}}$ & $2.4^{\text {def }}$ & $41.7^{\mathrm{hi}}$ & $3.4^{\text {ef }}$ & $45.0^{\text {ghi }}$ \\
\hline Kontrol & \multirow{4}{*}{140 Ruggeri } & $10.7^{\text {de }}$ & $1.3^{h}$ & $2.6^{\text {def }}$ & $45.5^{\mathrm{fgh}}$ & $3.7^{\text {def }}$ & $49.2^{\text {efgh }}$ \\
\hline$\% 35$ & & $8.8^{\text {defg }}$ & $1.4^{\mathrm{h}}$ & $2.0 \mathrm{fg}$ & $34.4^{j}$ & $3.9^{\text {cdef }}$ & $38.3^{j}$ \\
\hline$\% 55$ & & $10.9^{d}$ & $1.7^{\mathrm{gh}}$ & $2.6^{\text {def }}$ & $38.3^{\mathrm{ij}}$ & $4.4^{\text {cdef }}$ & $42.8^{\mathrm{hij}}$ \\
\hline$\% 75$ & & $6.3^{g}$ & $1.5^{\mathrm{h}}$ & $2.2^{\text {efg }}$ & $22.8^{\mathrm{k}}$ & $8.3^{a b}$ & $31.1^{\mathrm{k}}$ \\
\hline Kontrol & \multirow{4}{*}{$1613 C$} & $18.0^{\mathrm{ab}}$ & $2.8^{\mathrm{cd}}$ & $4.0^{a}$ & $49.2^{\text {def }}$ & 3.1 ef & $52.3^{\text {def }}$ \\
\hline$\% 35$ & & $13.9^{c}$ & $3.4^{\mathrm{ab}}$ & $3.9^{\mathrm{ab}}$ & $47.4^{\mathrm{efg}}$ & $4.6^{\text {cdef }}$ & $52.1^{\text {def }}$ \\
\hline$\% 55$ & & $16.1^{\mathrm{abc}}$ & $3.5^{\mathrm{a}}$ & $3.9^{a b}$ & $53.3^{c d}$ & $4.5^{\text {cdef }}$ & $57.9^{c d}$ \\
\hline$\% 75$ & & $7.8^{\text {efg }}$ & $2.5^{\mathrm{de}}$ & $3.8^{\mathrm{ab}}$ & $33.5^{j}$ & $5.4^{\text {cde }}$ & $38.9^{\mathrm{ij}}$ \\
\hline Kontrol & \multirow{4}{*}{$5 \mathrm{BB}$} & $15.3^{b c}$ & $3.1^{b c}$ & $4.0^{a}$ & $49.3^{\text {def }}$ & $2.1^{f}$ & $51.4^{\text {efg }}$ \\
\hline$\% 35$ & & $18.7^{a}$ & $2.9^{\mathrm{cd}}$ & $4.0^{\mathrm{ab}}$ & $53.8^{\mathrm{bcd}}$ & $6.2^{\mathrm{bcd}}$ & $60.0^{b c}$ \\
\hline$\% 55$ & & $16.6^{\mathrm{abc}}$ & $2.9^{\mathrm{cd}}$ & $3.9^{\mathrm{ab}}$ & $58.8^{\mathrm{ab}}$ & $6.6^{b c}$ & $65.4^{\mathrm{ab}}$ \\
\hline$\% 75$ & & $8.7^{\text {defg }}$ & $2.5^{\mathrm{de}}$ & $3.9^{\mathrm{ab}}$ & $41.7^{\mathrm{hi}}$ & $10.7^{\mathrm{a}}$ & $52.2^{\text {def }}$ \\
\hline Kontrol & \multirow{4}{*}{ Ramsey } & $10.7^{\text {de }}$ & $1.3^{h}$ & $2.7^{\text {cdef }}$ & $45.0^{\mathrm{fgh}}$ & $4.0^{\text {cdef }}$ & $49.0^{\text {efgh }}$ \\
\hline$\% 35$ & & $9.3^{\text {def }}$ & $1.6^{\mathrm{gh}}$ & $2.3^{\mathrm{defg}}$ & $42.2^{\mathrm{ghi}}$ & $2.7^{\text {ef }}$ & $44.9^{\mathrm{hi}}$ \\
\hline$\% 55$ & & $8.9^{\text {defg }}$ & $2.2^{\text {ef }}$ & $2.4^{\text {def }}$ & $63.0^{\mathrm{a}}$ & $4.0^{\text {cdef }}$ & $67.0^{a}$ \\
\hline$\% 75$ & & $6.3^{g}$ & $1.3^{\mathrm{h}}$ & $1.6^{\mathrm{g}}$ & $35.4^{j}$ & $4.5^{\text {cdef }}$ & $39.9^{\mathrm{ij}}$ \\
\hline $\operatorname{LSD}_{(0,05)}$ & & 2.9 & 0.4 & 0.7 & 5.4 & 2.8 & 6.4 \\
\hline
\end{tabular}

Aynı sütundaki farklı harfler önemlidir $(0,05)$

İncelenen özelliklerin tamamı kullanılan anaçlara, gölge oranlarına ve anaç $x$ gölge interaksiyonuna göre istatistiki bakımdan önemli bulunmuştur. Anaçlar kök sayısı bakımından 14,8 adet (5 BB) ile 8,0 adet (110 R) arasında yer alırken kök gelişimi bakımından ise 3.1
(1613 C) ile 1,6 (Ramsey) arasında değer almışlardır. Anaçların Sultani Çekirdeksiz üzüm çeşidine ait sürgün gelişimine etkisi 4.0 (5 BB) ile 2.2 (Ramsey) arasında gerçekleşmiştir. Toplam fidan randımanı bakımından \% 57.3 ile $5 \mathrm{BB}$ anacı en fazla randımanı değerine sahip 
olurken 140 Ruggeri anacı \% 40,4 fidan randımanı değerine ulaşmıştır (Çizelge 2). Genel olarak elde edilen değerler köklenmesi zor olan anaçlarda (140 ruggeri ve 110 R) düşük olurken köklenmesi kolay olan anaçlarda (5 BB ve 1613 C) yüksek bulunmuştur. Amerikan asma anaçlarının köklenme kabiliyetleri genetik faktörler tarafından belirlenmektedir. Bazı anaçlara ait çelikler ( 5 BB, SO4, 1613 C vb) daha kolay köklenirken bazı anaçlara ait çeliklerde (140 Ruggeri, $110 \mathrm{R}, 41 \mathrm{~B} \mathrm{vb}$ ) ise köklenme daha düşük seviyelerde kalabilmektedir (Çelik, 1996; Çelik, 1998; Çelik ve ark., 1998).

Farklık gölge oranlarına sahip netler altında yetiştirilen fidanlarda; fidan kalitesi olarak değerlendireceğimiz kök sayısı, kök ve sürgün gelişim değerleri kontrol uygulamasından elde edilirken fidan randımanı bakımından en iyi performansı \%55 gölge altında yetiştirilenlerden elde edilmiştir. \% 55 gölge altındaki bu fidan randıman değeri kontrole göre \%20'lik bir iyileştirme meydana getirmiştir (Çizelge 2).

Anaç $x$ Gölge interaksiyonu bakımından değerlendirmede ise; 18.7 adet (5 BB-\%35 gölge) ile 6.3 adet (140 Ruggeri-\%75 gölge ve Ramsey-\%75 gölge) arasında kök sayısı; 3.5 (1613 C- \%55 gölge) ile 1,3 (çeşitli) arasında kök gelişimi; 4.0 (1613 C-Kontrol, 5 BB-\% 35 ve 55 gölge) arasında sürgün gelişimi; $\% 67.0$ (Ramsey - \%55 gölge) ile \% 31.1 (140 Ruggeri-\%75 gölge) arasında fidan randımanı elde edilmiştir (Çizelge3).

Asma fidanı üretimi ile ilgili yapılan çalışmalarda kök sayısı, kök ve sürgün gelişimi değerleri; kullanılan amerikan asma anacına, çeşitlere, sulama aralıklarına, malç tipine, hormon seviyesine ve köklenme ortamına göre farklılıklar gösterebilmektedir (Çelik, 1995; Kelen ve Demirtaş, 2001; Küçükyumru, 2009; Yağcl ve ark., 2012). Yapılan bu çalışmada gölge uygulamaların da kök sayısını etkileyebileceği fakat hepsinden de yeterli sayıda kök oluşabileceği görülmüştür.

\section{SONUÇ}

Araştırma sonucunda farklı gölgeleme oranına sahip netler altında; sıcaklık ve nem değerleri birbirlerine yakın olurken ışıklanma miktarında farklılık oluşmuştur.

\section{KAYNAKLAR}

Akman, İ., Ilgın, C., 1987. Tüplü fidan Üretiminde Başarıyı etkileyen Faktörler ,TÜBİTAK Türkiye 1.Fidancılık Sempozyumu Bildirileri S. 52

Akman, İ., Ilgın, C., 1991. Tüplü Asma Fidanı Üretiminde Başarıyı Etkileyen Faktörler. Türkiye 1. Fidancıllk Sempozyumu, 153-159, Ankara.

Anonim, 2014. http://www.tarim.gov.tr/BUGEM/Menu/9/Veriler.html (Ziyaret Tarihi: 25.09 .2014 )
Daha yoğun gölgeleme uygulaması altındaki fidanların hem toprak altı hem de toprak üstü gelişimleri diğer uygulamalardakilere göre daha zayıf olduğu tespit edilmiştir. Buna neden olarak; ışıklanmanın az olması fotosentezi azaltmakta bu da fidanların beslenmesinde yetersizlikler oluşmasına neden olduğu düşünülmektedir. Aynı zamanda gölgeleme oranı arttıkça, özellikle yağışı dönemlerde yoğun gölge altında bulunan fidanların mantari hastalıklara yakalanma riskini de artırmaktadır. Buna nem tutma özelliğinin yanı sıra, ışıklanma miktarının da daha düşük olması ve dolayısıyla nem kaybının yavaş olmasının sebep olduğu düşünülmektedir.

Kök sayısı, kök gelişim düzeyi, sürgün gelişme düzeyi, toplam fidan randımanı, I. boy fidan randımanı ve II. boy fidan randımanı değerleri hem gölge düzeylerinden hem anaçlardan hem de gölge $x$ anaç interaksiyonundan önemli derecede etkilenmiştir. Özellikle fidan randımanı bakımından en iyi değeri \%55 gölge materyali almıştır. Fakat kök sayısı ve sürgün gelişim seviyesi \%55 gölge altında daha az değerlere sahip olmuştur.

Manisa ili en fazla asma fidan üreten il olması ve buradan elde edilen fidanların tüm Türkiye'ye yayıldığı; randıman artırıcı/maliyeti azaltıcı uygulamalardan özellikle $\% 55$ gölge uygulamasının başarılı bir şekilde kullanılabileceği düşünülebilir. Ayrıca Manisa ilinde büyük fidancıların bulunması aşı ve dikim tarihlerinin daha geç bir zamanda yapılıyor olması nedeniyle gölge uygulamaları ile sıcakların etkisinden korunmada daha etkili olabileceği düşünülmektedir.

Bunun gibi çalışmalar farklı anaç ve çeşit kombinasyonlarında; örtünün farklı zamanlarda kaldırılma uygulamalarında; değişik toprak tiplerinde ve farklı yüksekliklere sahip iskelet malzemelerinde ve birkaç yıl denenmesinde fayda görülmektedir.

\section{TEŞEKKÜR}

Açık köklü asma fidanı üretiminde arazisini kullandığımız Murat PEHLiVANLAR'a teşekkür ederiz.

Cangi, R., Doğan, A.ve Kelen, M., 1999. Aşılı Köklü Asma Fidan Üretiminde Köklü Anaç Kullanımının Aşı Yerinde Kallus Oluşumu ve Fidan Randımanı Üzerine Etkileri. O.M.Ü. Zir. Fak. Der.

Cartechini, A. ve Palliotti, A., 1995. Effect of Shading on Vine Morphology and Productivity and Leaf Gas Exchange Characteristics in Grapevines in The Field. Am. J. Enol. Vitic. $46: 2: 227-234$. 
Çelik, H. ve Ağaoğlu, Y.S., 1979. Assılı Köklü Asma Fidanı Üretiminde Farklı Çeşit/Anaç Kombinasyonlarının Aşııda Başarı Üzerine Etkileri. Ankara Üniversitesi Ziraat Fakültesi Yıllığı, Cilt:29, Fasikül L'den Ayrı Basım.

Çelik, H., Ağaoğlu, Y.S., 1981. Aşılı Köklü Asma Fidanı Üretiminde Farklı "Çeşit/Anaç" Kombinasyonlarının Aşıda Başarı ile Fidan Verim ve Kalitesi Üzerine Etkileri. Ankara Üniv. Ziraat Fak. Yayınları:766, Bilimsel Araştırma Ve İncelemeler: 452, 19.

Çelik, H., Ardalı, T., Çetin, H., Sucu, R., 1996. Doğrudan Fidanlığa Dikilen Aşılı Asma Çeliklerden Fidan Üretiminde Başarı Üzerine Siyah Plastik Tünel ve Örtü Materyallerinin Etkileri. Tarım Bilimleri Dergisi 2(3), 33-38s.

Çelik, H., Ağaoğlu, Y.S., Fidan, Y., Marasalı, B. ve Söylemezoğlu, G., 1998. Genel Bağcllı, Sun Fidan, 253 s.

Çelik, H. ve Odabaş, F., 1995. Farklı Anaçlar Üzerine Aşılanan Bazı Üzüm Çeşitlerinde Aşı Tipi ve Aşılama Zamanlarının Fidanların Büyüme ve Gelişmesi Üzerine Etkileri. Türkiye II. Ulusal Bahçe Bitkileri Kongresi Bildirileri, 3-6 Ekim, Adana.

Çelik, H., Odabaş, F., 1996. Farklı Örtü Materyallerinin Aşılı Çeliklerden Asma Fidanı Elde Etmede Başarı Üzerine Etkileri. Ondokuz Mayıs Üniversitesi Ziraat Fakültesi Dergisi, sayı: 11.3, $73-85$ s

Çelik, H., 1982. Kalecik Karası/ 41 B Aşı Kombinasyonu İçin Sera Koşullarına Yapılan Asma Fidanı Üretiminde Değişik Köklendirme Ortamları ve NAA Uygulamasının Etkileri. Doçentlik Tezi, 73s

Çelik, H., 1995. Samsun İli Fidanlık Şartlarında Aşılama Yoluyla Assılı Asma Fidanı Üretiminde Așı Tipi ve Assılama Zamanlarının Etkileri. 19 Mayı Üniversitesi, Fen Bilimleri Enstitüsü.

Çelik, H., Ardalı, T., Çetin, H., Sucu, R., 1996. Doğrudan Fidanlığa Dikilen Aşılı Asma Çeliklerden Fidan Üretiminde Başarı Üzerine Siyah Plastik Tünel ve Örtü Materyallerinin Etkileri. Tarım Bilimleri Dergisi 2(3), 33-38s.

Çelik, H., 1998. Fidanlık Şartlarında ve El İle Çalışan Aşı Makineleriyle Uygulanan Farklı Aşılama Yöntemlerinin Assıda Başarı Üzerine Etkileri. IV. Bağcılık Sempozyumu Bildirileri. 362-367. 20-23 Ekim 1998, Yalova.

Çelik, K., Çelik, S., Kunter, B.M., Söylemezoğlu, G., Boz, Y., Özer, C. ve Atak, A., 2005. Bağcllıkta Gelişme ve Üretim Hedefleri, VI. Türkiye Ziraat Mühendisliği Teknik Kongresi, 3-7 Ocak, Ankara.

Çelik, S., 2011. Bağcllk (Ampeloloji). Namık Kemal Üniversitesi Ziraat Fakültesi Bahçe Bitkileri Bölümü, Avcı Ofset, İstanbul

Ece M., 2003. Isparta Koşullarında Bazı Çeşit-Anaç Kombinasyonlarının Karşılaştırılması. Süleyman Demirel Üniversitesi, Yüksek Lisans Tezi.

Ecevit, F. ve Göktürk Baydar, N., 2000. Assılı Asma Fidanı Üretiminde Farklı Aşılama Yöntemlerinin Aşıda Başarı Üzerine Etkileri. II. Ulusal Fidancilı Sempozyumu Bildirileri, 25-29 Eylül 2000, Ödemiş/İzmir.

Erdem, B. ve Ergenoğlu, F., 1995. Köklü Amerikan Asma Anaçlarından Fidan Eldesinde En Uygun Aşı Yöntemi ve Zamanının Saptanması. Türkiye II. Ulusal Bahçe Bitkileri Kongresi Bildirileri. II. Cilt, 500-503. 3-6 Ekim, 1995, Adana.

Eriş, A., Soylu, A., Türkben, C., 1989. Assılı Köklü Asma Fidanı Ürtiminde Bazı Uygulamaların Aşı Yerinde Kallus Oluşumu ve Köklenme Üzerine Etkileri. Yalova Atatürk Bahçe Kültürleri MErkez Araştırma Enstitüsü Dergisi Bahçe 18(1-2),29-34
Kelen, M. ve Demirtas, İ., 2001. 5BB ve 420 A Amerikan Asma Anaçlarının Köklenme Oranları ve Kök Kaliteleri Üzerine Farkl Köklendirme Ortamları ile IBA dozlarının etkileri. Tarım Bilimleri Dergisi 7 (1): 142-146.

Kelen, M., 1994. Bazı Uygulamaların Așılı Köklü Asma Fidanı Üretiminde Fidan Kalite ve Randımanı Üzerine Etkileri ile Aşı Kaynaşmasının Anatomik ve Histolojik Olarak İncelenmesi Üzerine Araştırmalar. Y.Y.Ü Fen Bilimleri Enstitüsü, Doktora Tezi, $131 \mathrm{~S}$, Van

Kesgin, M., 2011. Sofralık Amaçlı Sultani Çekirdeksiz Üzüm Yetiştiriciliğinde Gölgeleme-Örtü Materyali Uygulamalarının Hasadı Geciktirme ve Üzüm Kalitesine Etkisi. Gaziosmanpaşa Üniversitesi Fen Bilimleri Enstitüsü. Yüksek Lisans Tezi.

Kısmalı, İ., 1978. Yuvarlak Çekirdeksiz Üzüm Çeşidi ve Farkh Amerikan Asma Anaçları ile Yapılan Aşılı- Köklü Asma Fidanı Üretimi Üzerinde Araştırmalar. Basılmamış Doçentlik Tezi, 102 S. İzmir.

Köse, B., 2006. Samsun Ekolojik Şartlarında Tüplü Asma Fidanı Yetiştiriciliğinde Işık ve Sıcaklığın Vegetatif Gelişme ve Fidan Kalitesi Üzerine Etkisinin Saptanması. 19 Mayıs Üniversitesi, Fen Bilimleri Enstitüsü, Doktora Tezi.

Küçükyumuk, C., 2009. Aşılı Asma Fidanı Üretiminde Farklı Sulama Aralıkları ve Malç Uygulamalarının Fidan Randımanı ve Kalitesi Üzerine Etkileri. Süleyman Demirel Üniversitesi, Fen Bilimleri Enstitüsü

Sağlam, H., Yağcı, A., Ö.Ç.Sağlam. 2005. Bazı Amerikan Asma Anaçlarında Iba Kullanımının Fidan Kalite Ve Randımanına Etkileri Üzerine Araştırmalar. Türkiye 6. Bağcılık Sempozyumu Bildirileri, Cilt: I, Sayfa No: 554-560, Tekirdağ

Samancı, H. ve Uslu, İ., 1992. Așılı Köklü Asma Fidanı Üretiminde Randıman ve Kalitenin Çeşit/Anaç Kombinasyonlarına Göre Değişiminin Araştırılması. Tarım ve Köy İşleri Bakanlığı, Bağcllık Araştırma Projesi.

Sivritepe, N., ve Türkben, C., 2001. Müşküle Üzüm Çeşidinde Farklı Anaçların Aşıda Başarı ve Fidan Randımanı Üzerine Etkileri. Uludağ Üniversitesi Ziraat Fakültesi Dergisi. 15:47-58s

Sucu S ve Yağcı A (2015). Aşılama Öncesi Amerikan Asma Anaçlarına Ön Bekletme Uygulamalarının Fidan Randıman Üzerine Etkileri. Selçuk Tarım ve Gıda Bilimleri Dergisi - A27, (Türkiye 8. Bağcılık ve Teknolojileri Sempozyumu Özel Sayısı), s 450-456, Konya.

TSE, 1995. Türk Standartları Enstitüsü, “TSE 3981; Asma Fidan”, 10s.

Westhuizen, J. H., 1980. The Use of Plastic Soil Cover in the Nursery. Vitis 19 (3)

Winkler, A.J., Cook, J.A.,Kliewer, W.M. and Lider, L.A., 1997. General Viticulture. Univ. Calif. Press, Berkeley and Los Angeles, $710 \mathrm{p}$.

Yağcı, A., Aydin, S., Cangi, R., Topçu, N., Sucu, S., Kılıç, D., Akgül, S.D., 2012. Determination of Effects on Grapevine Production of Different Shading Ratios. The XXXVrd World Congress Of Vine And Wine 10th General Assembly Of The O.I.V. June 18 - 22, 2012, Izmir (Turkey).

Yağcı A ve Aydin S (2012). Açık Köklü Asma Fidani Üretiminde Farklı Gölgeleme Oranlarının Fidan Randıman Ve Kalitesine Etkileri. Selçuk Tarım ve Gıda Bilimleri Dergisi - A27, (Türkiye 8. Bağcıllk ve Teknolojileri Sempozyumu Özel Sayısı), s146-153, Konya. 